\title{
Studi Microgrid System Menuju Pembangunan Desa Mandiri Energi Di Desa Temajuk Kabupaten Sambas
}

\author{
Yunando $^{1)}$, Sutriyatna ${ }^{2)}$ \\ ${ }^{1,2)}$ Magister Teknik Elektro Universitas Tanjungpura Pontianak \\ ${ }^{1)}$ Analis Kelaikan Teknis Migas Kementerian ESDM, Dirjen Minyak dan Gas Bumi \\ ${ }^{2}$ Staf Pengajar Jurusan Teknik Mesin Politeknik Pontianak \\ e-mail : yunandolubis@gmail.com
}

\begin{abstract}
Temajuk Village is one of the villages in Kecamatan Paloh Sambas regency, West Kalimantan Province, which borders directly with Sarawak (Malaysia). From 1980 to 2011 Desa Temajuk has no permanent electricity yet. In 2011, the village will have electrical energy by utilizing local energy such as Micro Hydro Power Generation, by 2012, Centralized Solar Power Generation and by 2015 Diesel Power Plant, all of which will carry each load without being integrated with the same network. So it is necessary to do the study of merging a network that is connected to one another to be able to bear the same load.

Microgrid System study was then created with the aim of producing a sustainable distribution network study by combining 3 different types of plants and operational savings from the use of diesel fuel oil costs as the main power plant after the network system.
\end{abstract}

\section{Keywords- Microgrid System, cost savings}

\section{Pendahuluan}

Sejalan dengan semakin meningkatnya laju pertumbuhan penduduk dan kegiatan pembangunan di segala bidang, listrik telah menjadi kebutuhan dasar pokok bagi manusia. Untuk memenuhi kebutuhan listrik yang semakin pesat, Pemerintah melakukan peningkatkan program pembangunan sarana dan prasarana tenaga listrik untuk menjangkau wilayah yang belum memiliki akses listrik.

Sebagian besar wilayah Kalimantan Barat, y $\mathbf{2} \mathbf{d}$ ada di wilayah pedalaman atau daerah-daerah terpencil (remote area), masih belum memiliki atau mendapatkan akses infrastruktur energi listrik sebagaimana daerahdaerah pesisir dan perkotaan. PT. PLN (Persero) Wilayah Kalimantan Barat, yang melayani kebutuhan kebutuhan energi listrik untuk wilayah Kalimantan Barat, menghadapi beberapa kendala untuk elektrifikasi daerah-daerah tersebut. Seperti kondisi geografis, wilayah yang sangat luas, prasarana transportasi yang masih belum memadai, kerapatan penduduk yang relatif kecil sedangkan jarak antara desa ke desa lainnya relatif jauh, anggaran belanja investasi sarana sistem kelistrikan yang masih terbatas dan lain-lain, sehingga elektrifikasi daerah-daerah pedalaman (remote area) dan terpencil masih mengalami kendala sehingga belum dapat dilakukan pengembangan infrastruktur energi listrik secara optimum. Akibat adanya keterbatasan ekonomi maupun kondisi geografis, sistem penyaluran listrik secara tersentralisasi belum bisa melingkupi semua daerah yang membutuhkan.

Dengan memanfaatkan sumber energi terbarukan lokal yang tersedia dimasing-masing wilayah, microgrid system dapat dijadikan suatu solusi untuk mewujudkan Daerah Mandiri Energi bagi daerah yang tidak ada atau belum terjangkau layanan listrik PLN.

Desa Temajuk adalah sala satu desa di Kecamatan Paloh Kabupaten Sambas Provinsi Kalimantan Barat yang berbatasan langsung dengan Negara Malaysia Sarawak Timur. diantara strategi dan solusi dari permasalahan diatas adalah perlu adanya program evaluasi kehandalan secara terus menerus dan terpadu.

Konsep evaluasi kehandalan yang diterapkan adalah penerapan metode-metode optimasi. Prediksi demand dan supply untuk perbaikan kualitas daya/power quality, mengurangi rugi-rugi daya/power losses serta meningkatkan efisiensi biaya pembangkitan dan distribusi dengan dukungan teknologi informasi dan komunikasi. dimana tujuan penelitian ini adalah untuk menghasilkan studi jaringan distribusi microgrid system pada Desa Temajuk yang berkelanjutan dengan menggabungkan 3(tiga) jenis pembangkit berbeda dan penghematan operasional dari sisi penggunaan biaya bahan bakar minyak jenis solar PLTD sebagai pembangkit utama setelah penggabungan system jaringan.

\section{Tinjauan Pustaka}

\section{A. Pengertian Microgrid System}

Sebuah microgrid dapat berupa pusat perbelanjaan, kawasan industri, kampus atau pemukiman yang terpencil(isolated area). Untuk kegunaan, microgrid adalah sebuah beban listrik yang dapat dikontrol besarnya. Beban bisa konstan, atau beban bisa meningkat pada malam hari ketika listrik lebih murah, atau beban bisa diadakan di nol selama saat stress system. Diketahui bahwa sumber energi baru terbarukan sangat fluktuatif dan sulit diprediksi secara pasti, sehingga tenaga yang dihasilkan pun akan berfluktuatif terhadap waktu. Sedangkan dipihak pelanggan(demand) diharapkan terjaminnya kestabilan tegangan dan frekuensi sehingga disinilah pentingnya pengendali yang handal. Sedangkan untuk mengatasi ketidak pastian daya(power) yang dihasilkan, diperlukan sumber tenaga lain seperti Pembangkit Listrik Tenaga Diesel (PLTD) 
yang diparalel sehingga sistem seperti ini sering disebut HybridPower Generation.

Microgrid merupakan salah satu contoh pola pembangkitan terdistribusi yang bisa melingkupi berbagai macam sumber energi, mulai dari sumber fosil, maupun sumber energi baru terbarukan seperti, angin, surya, biogas, mikrohydro dan sebagainya. Secara definisi microgrid merupakan sistem interkoneksi beban dan berbagai macam sumber energi yang terdistribusi, sebagai satu system microgrid dapat beroperasi paralel dengan sistem interkoneksi yang lebih besar atau beroperasi mandiri.

Komponen microgrid terdiri dari :

1. Distributed Generation (micro source) Pembangkit (sumber kecil), didefinisikan sebagai pembangkit tenaga listrik pada jaringan distribusi atau pada sisi jaringan pelanggan.

2. Load_Beban, didefinisikan sebagai konsumsi tenaga listrik dalam kurun harian, bulanan maupun tahunan.

3. Intermediate Storage Penyimpanan

4. Point of common coupling titik penyambungan pembangkit.

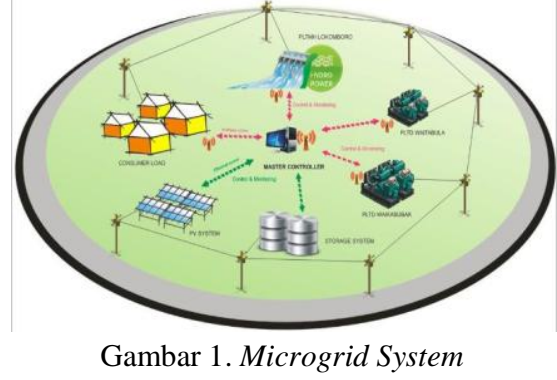

B. Karakteristik Pembangkit Listrik Tenaga Mikro Hidro

Pembangkit Listrik Tenaga Mikro Hidro (PLTMH) adalah suatu pembangkitan energi listrik dengan mengubah energi potensial air menjadi energi mekanik oleh turbin dan diubah lagi menjadi energi listrik oleh generator dengan memanfaatkan ketinggian dan kecepatan aliran air. Bentuk utama dari pembangkit listrik jenis ini adalah generator yang dihubungkan ke turbin yang digerakkan oleh air. Data yang dikumpulkan pada kegiatan studi ini meliputi :

1. Data pembangkit tentang PLTMH yang telah terbangun.

2. Data luas jaringan dan jenis jaringan yang digunakan. Total energi yang didapat pada reservoir air sebanding dengan besarnya energi potensial yang dimiliki oleh air tersebut.

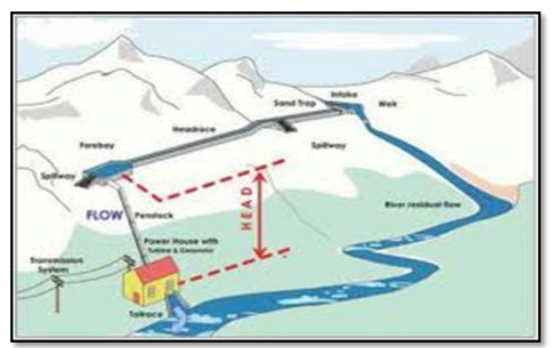

Gambar 2. Pembangkit Listrik Tenaga Mikro Hidro
Menurut Khaerul, 2008, berdasarkan kapasitas outputnya, pembangkit listrik dibedakan menjadi :

- PLTA besar memiliki kapasitas output listrik > $10 \mathrm{MW}$;

- PLTA kecil memiliki kapasitas output listrik 1-10 MW;

- Minihidro memiliki kapasitas output listrik 100 KW - 1 MW;

- Mikrohidro memiliki kapasitas output listrik $1 \mathrm{KW}-100 \mathrm{KW}$;

- Pikohidro memiliki kapasitas output listrik < $1 \mathrm{KW}$.

C. Karakteristik Pembangkit Listrik Tenaga Surya Terpusat

Sistem Pembangkit Listrik Tenaga Surya (PLTS)

Photovoltaic (biasanya disebut juga sel surya) adalah semikonduktor yang dapat merubah cahaya secara langsung menjadi arus listrik searah (DC) dengan menggunakan cristal silicon (Si) yang tipis. Sel-sel silicon itu dipasang dengan posisi sejajar/seri dalam sebuah panel yang terbuat dari alumunium atau baja anti karat dan dilindungi oleh kaca atau plastik. Kemudian pada tiap- tiap sambungan sel itu diberi sambungan listrik. Bila sel-sel itu terkena sinar matahari maka pada sambungan itu akan mengalir arus listrik. Besarnya arus/tenaga listrik itu tergantung pada jumlah energi cahaya yang mencapai silikon itu dan luas permukaan sel itu.

Data yang dikumpulkan pada kegiatan studi potensi ini meliputi :

- Menentukan Total Beban (Load)

- Data total beban diperlukan untuk menghitung kapasitas PLTS yang diperlukan. Selain itu data tersebut diperlukan untuk mengetahui apakah kapasitas PLTS yang diperlukan tersedia di pasaran.

- Kapasitas Daya Modul Surya (PV).

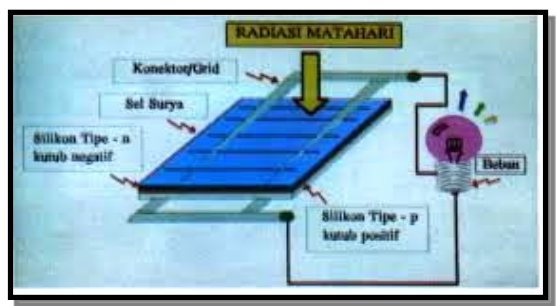

Gambar 3. Cara Kerja Photovoltaic

D. Karakteristik Pembangkit Listrik Tenaga Diesel

Pembangkit Listrik Tenaga Diesel (PLTD) ialah pembangkit listrik yang menggunakan mesin diesel sebagai penggerak mula (prime mover). Prime mover merupakan peralatan yang mempunyai fungsi menghasilkan energi mekanis yang diperlukan untuk memutar rotor generator. Mesin diesel sebagai penggerak mula PLTD berfungsi menghasilkan tenaga mekanis yang dipergunakan untuk memutar rotor generator.

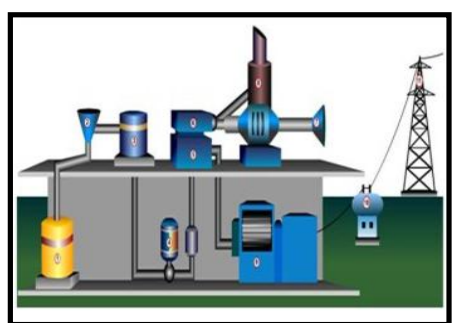

Gambar 4. Pembangkit Listrik Tenaga Diesel 


\section{E. Jaringan Distribusi Microgrid System}

Microgrid System, yang secara umum ditunjukan pada gambar 1 pada dasarnya adalah design pengaturan pembangkit tenaga listrik yang membagikan beban lokal bagi pembangkit-pembangkit di dalam microgrid system sebagai bagian dari sebuah jaringan sistem tenaga listrik.

Interaksi microgrid ke jaringan-jaringan distribusi dilakukan sebagai pengguna yang menyerap sebagian kebutuhan lokalnya di jaringan-jaringan tersebut, sekaligus sebagai penyedia tenaga listrik ke jaringanjaringan bila terdapat kelebihan kapasitas produksi di dalam microgrid. Dengan demikian microgrid diharapkan akan dapat melepaskan diri sendiri dan berdiri sendiri bila terjadi gangguan sistem secara keseluruhan, sekaligus menopang sistem tenaga kelistrikan secara keseluruhan pada kondisi operasi normal.

Prinsip pengaturan sistem operasi microgrid diatas, dapat diterapkan pada beberapa pembangkit energi baru terbarukan maupun tak terbarukan yang lokasinya berdekatan dan sudah memikul beban lokalnya masingmasing, sehingga akan dapat dicapai peningkatan ketersedian dan ketahanan supply tenaga listrik para konsumen pengguna di dalam microgridtersebut. Pada tahapan ini microgrid tersebut mungkin belum terhubung dengan jaringan tenaga listrik utama, tetapi bila situasi memungkinkan microgrid system tersebut dapat dihubungkan jaringan tenaga listrik utama.

Syarat-syarat pembangkit yang berbeda untuk bekerja secara paralel, yaitu :

- Tegangan ketiga pembangkit tersebut harus sama besar;

- Frekuensi harus sama;

- Phase ketiga pembangkit harus sama; dan

- Urutan phase ketiga pembangkit harus sama.

\section{Kondisi Objek Penelitian}

Desa Temajuk merupakan salah satu desa dari 8(delapan) desa yang berada di Kecamatan Paloh Kabupaten Sambas. Desa Temajuk secara geografis terletak pada koordinat $2^{0} 01$ ' 22.6' LU dan $109^{0} 37^{\prime}$ $00.5^{\prime}$ " BT. Desa Temajuk salah satu desa yang berbatasan langsung dengan Negara Malaysia Timur Sarawak. Desa Temajuk termasuk katagori daerah terisolir (remote area) karena letak geografisnya.

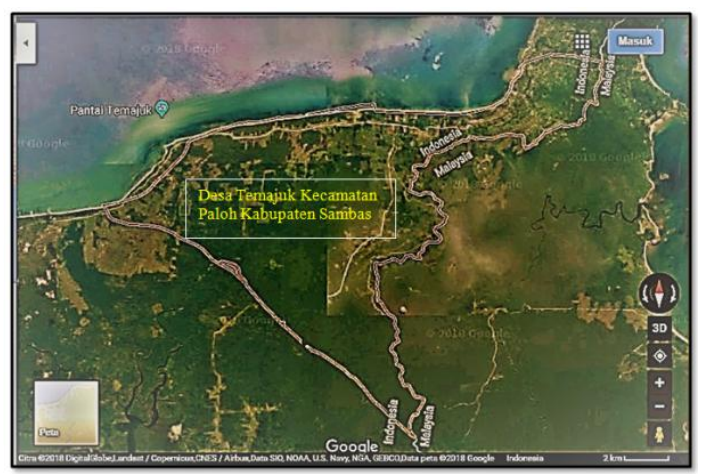

Gambar 5. Peta posisi geografis Desa Temajuk Kecamatan Paloh
A. Kondisi Kelistrikan

Pada saat ini Desa Temajuk memiliki 3(tiga) pembangkit yaitu Pembangkit Listrik Tenaga Diesel (PLTD), Pembangkit Listrik Tenaga Mikro Hidro (PLTMH) dan Pembangkit Listrik Tenaga Surya (PLTS) Terpusat (status standby). Kapasitas PLTMH daya terpasang 18kiloWatt dibangun pada tahun anggaran 2011 oleh Dinas Pekerjaan Umum Bina Marga Pengairan Energi dan Sumber Daya Mineral Kabupaten Sambas, PLTS Terpusat daya terpasang 80kiloWattpeak dibangun pada tahun anggaran 2014 oleh PT. PLN Wilayah Kalimantan Barat dan PLTD daya terpasang sebesar 235kiloVoltampere sebanyak 2(dua) unit mesin dibangun pada tahun anggaran 2015 oleh PT. PLN Wilayah Kalimantan Barat.

PLTMH melayani 25(dua puluh lima) konsumen yang berdekatan dengan pembangkit menggunakan jaringan tegangan rendah sepanjang \pm 2 kilometer, PLTS Terpusat melayani 70(tujuh puluh) konsumen dan penerangan jalan umum dengan menggunakan jaringan tegangan rendah sepanjang \pm 5 kilometer tapi saat ini tidak dioeprasikan lagi oleh PLN dan PLTD melayani 300(tiga ratus) konsumen menggunakan jaringan tegangan menengah, jaringan tegangan rendah.

Jadwal pengoperasian PLTMH melayani beban konsumen mulai pukul 18.00 sampai dengan 06.00 (12 jam/hari), PLTS Terpusat standby dan PLTD melayani beban konsumen serta fasilitas umum mulai pukul 18.00 sd 06.00 (12 jam/hari).

Jadwal operasional pembangkit-pembangkit di Desa Temajuk, yaitu :

1. Pembangkit Listrik Tenaga Mikro Hidro (PLTMH), yaitu :

- Saat ini waktu beroperasinya mulai pukul 18.00 sampai dengan 06.00 (12 jam).

- Melayani 25pelanggan.

- Wilayah area cakupan sekitar rumah pembangkit.

- Jaringan distribusi menggunakan tegangan rendah (SUTR) dengan panjang $\pm 2,5$ kilometer sirkuit dari pembangkit.

2. Pembangkit Listrik Tenaga Surya (PLTS) Terpusat, yaitu :

- Jaringan distribusi menggunakan tegangan rendah (SUTR) dengan panjang \pm 3 kilometer sirkuit dari pembangkit.

- Saat ini pembangkit dalam kondisi status standby.

3. Pembangkit Listrik Tenaga Diesel (PLTD).

A. Saat ini waktu beroperasinya mulai pukl 1800 sampai dengan 0600 (12jam).

B. Melayani jumlah pelanggansebanyak 300(tiga ratus).

C. Area cakupan jaringan distrubsinya yang tidak dilayani oleh PLTMH.

D. Jaringan distribusi mengunakan tegangan menengah (SUTM), jaringan tegangan rendah (SUTR) dan travo.

Tiap-tiap pembangkit tersebut diatas berdiri sendiri (stand alone) dengan melayani beban masing-masing di dalam wilayah jaringannya, begitu juga dengan sistem pengelolaannya. 


\section{B. Pengumpulan Data}

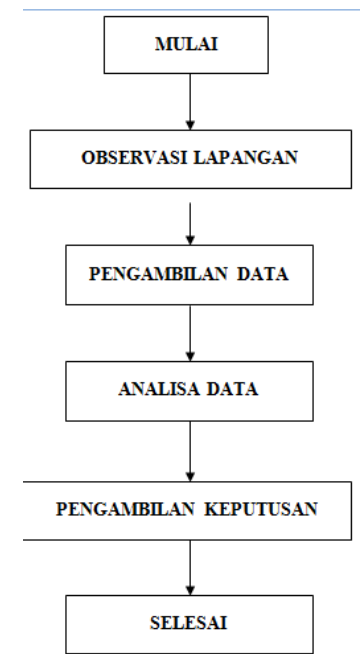

Gambar 6. Diagram alir Penelitian

Data dalam penelitian ini merupakan data hasil survey/observasi lapangan tempat dimana penelitian ini dilaksanakan. Adapun data-data yang terhimpun dari hasil survey/observasi yang dilakukan adalah data kapasitas pembangkit listrik dari sistem PLTD, PLTMH, PLTS Terpusat, data jumlah pelanggan tiap-tiap pembangkit.

Data kapasitas pembangkit listrik dari sistem PLTD meliputi merk mesin, tipe, nomor seri, tahun operasi, daya terpasang, daya mampu, merk load sharing, type load sharing, CT Ratio dan keterangan. Dan data kapasitas pembangkit listrik dari sistem PLTMH dan PLTS Terpusat meliputitipe, tahun pembuatan, daya terpasang, output rata-rata, tanggal operasi, kondisi pembangkit dan status asset.

E. Sistem PLTMH Off Grid di Desa Temajuk

Sistem PLTMH di Desa Temajuk merupakan jenis off grid atau stand alone dengan daya terpasang $18 \mathrm{~kW}$ dan didesain untuk melayani 25 pelanggan dengan jaringan distribusi tipe tegangan rendah sepanjang $2 \mathrm{~km}$ dari pembangkit, data tersebut bersumber dari Dinas Pekerjaan Umum Bina Marga Pengairan ESDM Kabupaten Sambas pada tahun 2011.

F. Sistem PLTS Terpusat Off Grid di Desa Temajuk

Sistem PLTS Terpusat di Desa Temajuk merupakan jenis off grid atau stand alone dengan daya terpasang $80 \mathrm{kWp}$ dan untuk melayani 70pelanggan dengan jaringan distribusi tipe tegangan rendah.

G. Sistem PLTD Off Grid di Desa Temajuk

Pembangkit Listrik Tenaga Diesel (PLTD) ialah Pembangkit listrik yang menggunakan mesin diesel sebagai penggerak mula (prime mover). PLTD memiliki daya terpasang $235 \mathrm{~kW} \times 2$ dan hanya 1(satu) yang beroperasi. Prime mover merupakan peralatan yang mempunyai fungsi menghasilkan energi mekanis yang diperlukan untuk memutar rotor generator. PLTD digunakan untuk memenuhi kebutuhan listrik dalam jumlah beban kecil, terutama untuk daerah baru yang terpencil (remote area) atau untuk listrik pedesaan.

\section{Hasil Dan Pembahasan}

a. Pembangkit Listrik Tenaga Mikro Hidro

Sumber daya energi air yang akan digunakan sebagai objek penelitian ini merupakan aliran sumber air bersih bagi masyarakat setempat. Menurut informasi masyarakat, ketersediaan sumber daya air tersedia sepanjang tahun dalam jumlah yang memadai. Potensi sumber daya energi air di Desa Temajuk antara lain meliputi Sungai Maludin, Teluk Melake, Pasir Pelaek dan Sungai Sekanji. Pengukuran sesaat debit air pada musim kemarau dan hujan serta informasi masyarakat menunjukkan tersedianya sumber daya air yang relatif terjamin sepanjang tahun dalam jumlah yang memadai.

- Pola Pembebanan

Lokasi Sungai Maludin berada pada ketinggian 207 meter dpl. Lokasi ini berada pada titik koordinat $02^{\circ} 01^{\prime} 22.6^{\prime \prime} \mathrm{LU}$ dan $109^{\circ} 37^{\prime} 0,5^{\prime}$ " BT, dengan head sepanjang 80 meter. Jarak terdekat sumber air ini dengan pemukiman penduduk sekitar 500 meter. Dengan debit air terukur sebesar 30 liter/detik sumber data dari Dinas Pekerjaan Umum Bina Marga Pengairan ESDM Kabupaten Sambas tahun 2011. Analisis potensi sumber daya air Sungai Maludin adalah sebagai berikut:

$P=(\rho \cdot Q \cdot g \cdot h) \cdot(\eta)$

$\rho=1.000 \mathrm{~kg} / \mathrm{m}^{3}$ (kondisi air standar)

$Q=30$ liter $/$ detik

$g=9.81 \mathrm{~m} / \mathrm{s}^{2}$

$h=80 m$

$\eta=0.70$

$P=1.000 \frac{\mathrm{kg}}{\mathrm{m}^{3}} \times \frac{30 \text { liter }}{\text { detik }} \times \frac{9.81 \mathrm{~m}}{\mathrm{~s}^{2}} \times 80 \mathrm{~m} \times 0.70 \%$

$=16480.800 \mathrm{Watt}$

$=16.48 \mathrm{~kW}$

Saat ini PLTMH masih beroperasi dan mensupply energi listrik ke konsumennya, yaitu sebanyak 24 pelanggan. Tiap rumah tangga tersebut dibatasi oleh pembatas arus sebesar $2 \mathrm{~A}$, sehingga daya yang dapat digunakan oleh konsumen rata-rata sebesar 450 watt. Besaran daya terpasang sebesar $18 \mathrm{~kW}$ dan output ratarata sebesar $10 \mathrm{~kW}$. Operasional PLTMH selama 12 jam mulai dari pukul 18.00 sampai dengan 06.00 setiap harinya tergantung debit air yang tersedia di bak penenang. Sumber data dari Dinas Pekerjaan Umum Bina Marga Pengairan ESDM Kabupaten Sambas.

Tabel 1. Kondisi PLTMH Saat Ini

\begin{tabular}{|c|c|c|c|c|c|}
\hline No. & $\begin{array}{l}\text { Jumlah } \\
\text { Pelanggan }\end{array}$ & $\begin{array}{l}\text { Waktu } \\
\text { (Hour) }\end{array}$ & $\begin{array}{l}\text { Daya Per } \\
\text { Rumah } \\
\text { (Watt) }\end{array}$ & Status & Keterangan \\
\hline 1. & 24 & $1800 \mathrm{sd} 0600$ & 450 & Running & $\begin{array}{l}\text { Setiap hari } \\
\text { (selama persedian } \\
\text { air masih } \\
\text { mencukupi }\end{array}$ \\
\hline
\end{tabular}

b. Pembangkit Listrik Tenaga Surya Terpusat

Sumber daya energi surya di Desa Temajuk sangatlah berlimpah karena termasuk wilayah garis khatulistiwa yang lama penyinarannya cukup lama yaitu mulai dari pukul 09.00 sampai dengan16.00. Sehingga sinar matahari dapat dimanfaatkan untuk diubah menjadi energi dan dimanfaatkan oleh masyarakat setempat. 
- Kapasitas Daya Modul Surya (PV)

Menentukan kapasitas daya modul surya diambil berdasarkan harga minimum insolasi matahari. Dengan total panel surya yang digunakan sebanyak $400 \mathrm{pcs}$, setiap modul surya mempunyai spesifikasi sebagai berikut :

Tegangan maksimum power $(\mathrm{Vmp})=38.0 \mathrm{VDC}$

Arus Maksimum Power $(\operatorname{Imp})=5.26 \mathrm{Amp}$

Wp permodul Surya $=200 \mathrm{Wp}$

Sehingga kapasitas total panel surya sebesar

Kapasitas Total Panel Surya $=400 p c s \times W p$ modul Surya

Kapasitas Total Panel Surya $=400 p c s \times 200 \mathrm{Wp}$

$=80.000 \mathrm{Wp}$

$=80 \mathrm{kWp}$

Kapasitas baterai sama dengan energi yang dihasilkan modul surya dibagi dengan daya yang dihasilkan modul,dikarenakan besarnya deep of discharge $(D O D)$ pada baterai $80 \%$.

$P=$ Daya yang masuk $\times 2 \%$

$=14.075,5 \times 2 \%$

$=281.51 \mathrm{Watt}$

Daya yang dihasilkan oleh Battery Charger ini adalah sebesar :

$P=14.075,5$ Watt -281.51 Watt

$=13.793,99 \mathrm{Watt}$

- Pola Pembebanan

Energi maksimal yang dihasilkan oleh PLTS Off Grid 80 $k W p$ dengan kondisi radiasi matahari $\geq$

$4.484 \frac{k W h}{m^{2} / d a y}$ adalah :

Energi Max $=$ Daya yang masuk $\times$ Kondisi radiasi matahari $=14.075,5 W$ att $\times \frac{4.484 k W h}{m^{2} / \text { day }}$

$=63.113,5$ Watt hour

Estimasi $k W h$ yang dihasilkan dalam 1 hari 63.113,5 atau $63.1 \mathrm{kWh}$.

Battery yang disediakan oleh sistem PLTS Terpusat ini adalah $144 \mathrm{kWh}$ dengan DOD 80\% maka energi maksimal yang bisa digunakan setiap hari adalah 115.2 $k W H$, tetapi disarankan untuk menggunakan DOD $50 \%$ sampai $60 \%$ atau $72 \mathrm{kWH}$ sampai $86.4 \mathrm{kWh}$ untuk memperpanjang umur battery yang digunakan.

Produksi Energi $=63 \mathrm{kWh}$

Energi Beban $=47 \mathrm{kWh}( \pm 75 \%)$

Data bersumber dari PT. PLN Area Singkawang Rayon Sekura.

c. Pembangkit Listrik Tenaga Diesel (PLTD)

PLTD Temajuk dibangun pada Tahun 2015 oleh PT. PLN (Persero) Kalimantan Barat. Memiliki 4 pembangkit dengan masing-masing kapasitas daya terpasang yaitu $235 \times 2$ status $\mathrm{OK}$ kondisi baru dan 140x2 status Standby kondisi bekas.

- Pola Pembebanan

Data yang digunakan adalah data beban harian PLTD Temajuk dalam sehari rata-rata menghasilkan 745.11 $k W h$ dengan menghabiskan bahan bakar minyak jenis solar rata-rata sehari 294.13 liter sehingga pemakaian bahan bakar minyak rata-rata per $k W h=0.39$ liter sumber data dari PT. PLN Area Singkawang Rayon Sekura. Pengambilan sampel beban harian PLTD mewakili nilai nominal beban minimum, rata-rata dan maksimum Januari 2017 untuk mewakili 1bulan lama pengoperasian.

Tabel 2. Data Beban Minimum PLTD Berdasarkan Waktu Pengoperasian

Tanggal 28 Januari 2017

\begin{tabular}{|c|c|c|}
\hline No. & Jam & Beban \\
\hline 1 & $1: 00$ & 41.1 \\
\hline 2 & $2: 00$ & 46.3 \\
\hline 3 & $3: 00$ & 44.8 \\
\hline 4 & $4: 00$ & 43.8 \\
\hline 5 & $5: 00$ & 47.5 \\
\hline 6 & $6: 00$ & 51.3 \\
\hline 7 & $7: 00$ & 0.0 \\
\hline 8 & $10: 00$ & 0.0 \\
\hline 9 & $13: 00$ & 0.0 \\
\hline 10 & $16: 00$ & 0.0 \\
\hline 11 & $18: 00$ & 75.1 \\
\hline 12 & $18: 30$ & 73.6 \\
\hline 13 & $19: 00$ & 73.1 \\
\hline 14 & $19: 30$ & 70.8 \\
\hline 15 & $20: 00$ & 68.1 \\
\hline 16 & $20: 30$ & 66.4 \\
\hline 17 & $21: 00$ & 65.0 \\
\hline 18 & $21: 30$ & 59.9 \\
\hline 19 & $22: 00$ & 56.4 \\
\hline 20 & $23: 00$ & 53.4 \\
\hline 21 & $0: 00$ & 48.9 \\
\hline
\end{tabular}

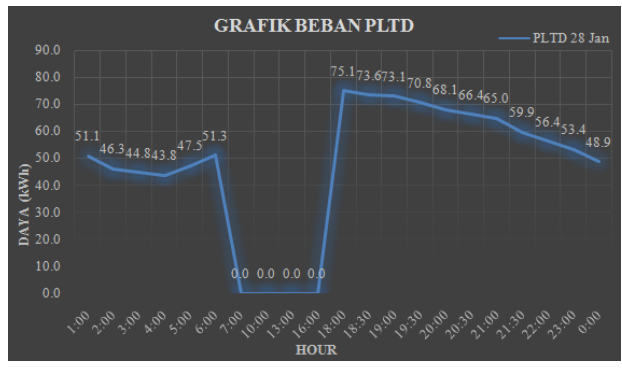

Gambar 7. Grafik Data Beban Minimum PLTD Tanggal 28 Januari 2017

Tabel 3. Data Beban Rata-Rata PLTD Berdasarkan Waktu Pengoperasian Tanggal 05 Januari 2017

\begin{tabular}{|c|c|c|}
\hline No. & Jam & Beban \\
\hline 1 & $1: 00$ & 47.2 \\
\hline 2 & $2: 00$ & 45.7 \\
\hline 3 & $3: 00$ & 43.4 \\
\hline 4 & $4: 00$ & 42.3 \\
\hline 5 & $5: 00$ & 54.7 \\
\hline 6 & $6: 00$ & 49.8 \\
\hline 7 & $7: 00$ & 0.0 \\
\hline 8 & $10: 00$ & 0.0 \\
\hline 9 & $13: 00$ & 0.0 \\
\hline 10 & $16: 00$ & 0.0 \\
\hline 11 & $18: 00$ & 76.4 \\
\hline 12 & $18: 30$ & 77.1 \\
\hline 13 & $19: 00$ & 74.5 \\
\hline 14 & $19: 30$ & 71.2 \\
\hline 15 & $20: 00$ & 71.5 \\
\hline 16 & $20: 30$ & 68.9 \\
\hline 17 & $21: 00$ & 60.8 \\
\hline 18 & $21: 30$ & 63.2 \\
\hline 19 & $22: 00$ & 58.6 \\
\hline 20 & $23: 00$ & 57.1 \\
\hline 21 & $0: 00$ & 54.5 \\
\hline
\end{tabular}




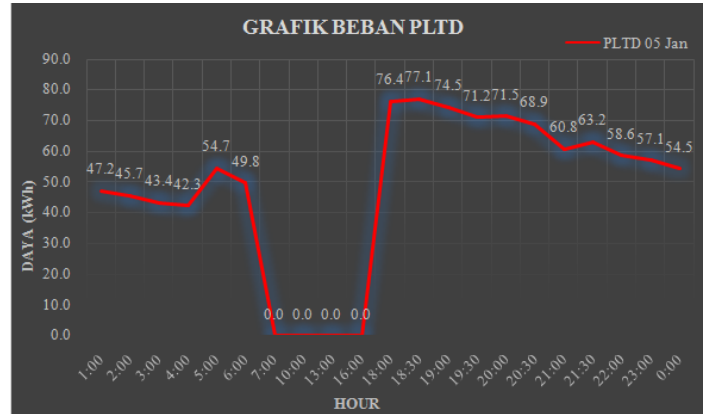

Gambar 8. Grafik Data Beban Rata-Rata PLTD Tanggal 05 Januari 2017

Tabel 4. Data Beban Maksimal PLTD Berdasarkan Waktu Pengoperasian Tanggal 22 Januari 2017

\begin{tabular}{|c|c|c|}
\hline No. & Jam & Beban \\
\hline 1 & $1: 00$ & 47.2 \\
\hline 2 & $2: 00$ & 47.2 \\
\hline 3 & $3: 00$ & 47.0 \\
\hline 4 & $4: 00$ & 43.2 \\
\hline $\mathbf{5}$ & $5: 00$ & 48.4 \\
\hline 6 & $6: 00$ & 54.6 \\
\hline 7 & $7: 00$ & 0.0 \\
\hline 8 & $10: 00$ & 0.0 \\
\hline 9 & $13: 00$ & 0.0 \\
\hline 10 & $16: 00$ & 0.0 \\
\hline 11 & $18: 00$ & 85.6 \\
\hline 12 & $18: 30$ & 79.2 \\
\hline 13 & $19: 00$ & 75.6 \\
\hline 14 & $19: 30$ & 77.7 \\
\hline 15 & $20: 00$ & 69.2 \\
\hline 16 & $20: 30$ & 66.7 \\
\hline 17 & $21: 00$ & 66.1 \\
\hline 18 & $21: 30$ & 63.8 \\
\hline 19 & $22: 00$ & 59.0 \\
\hline 20 & $23: 00$ & 56.1 \\
\hline 21 & $0: 00$ & 49.6 \\
\hline
\end{tabular}

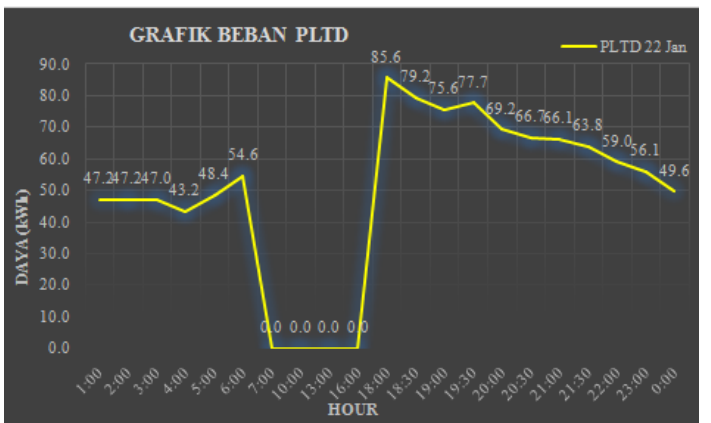

Gambar 9. Grafik Data Beban Maksimal PLTD Tanggal 22 Januari 2017

Saat ini PLTD melayani konsumen sebanyak 300 pelanggan. Besaran daya terpasang $235 \mathrm{~kW}$ dan daya mampu sebesar $200 \mathrm{~kW}$. Pembagian besaran daya tiaptiap pelanggan bervariasi mulai dari 900 watt sd 1300 watt. Operasional PLTD selama 12 jam di mulai dari pukul 18.00 sampai dengan 06.00 setiap hari dengan mesin PLTD yang beroperasi hanya satu unit. Data bersumber dari PT. PLN Area Singkawang Rayon Sekura tahun 2017.

Data-data yang dikumpulkan, yaitu :

Data harian beban PLTD Temajuk dari Januari sampai dengan Mei Tahun 2017.

Laporan PLTD Temajuk (bulan/tahun, BBM (liter) dan $k W h$ Produksi bulan Januari sampai dengan Mei 2017. Data-data tersebut dicatat oleh operator yaitu PLN
Temajuk Rayon Sekura. Sampel yang digunakan diambil bulan Januari 2017 pada tanggal 05, 22 dan 28 untuk beban minimum, rata-rata dan maksimum.Sumber data dari PT. PLN Area Singkawang Rayon Sekura.

Tabel 5. Data Laporan PLTD Temajok

\begin{tabular}{|c|c|c|c|c|c|}
\hline No. & Tanggal & kWh Produksi & $\begin{array}{l}\text { Pemakaian } \\
\text { BBM (Liter) }\end{array}$ & $\begin{array}{l}\text { Biaya Total } \\
\text { Produksi (Rp) }\end{array}$ & $\begin{array}{l}\text { Konsumsi } \\
\text { BBM/kWh }\end{array}$ \\
\hline 1 & $1 \operatorname{Jan} 2017$ & 721.30 & 285 & $2,163,900.00$ & 0.40 \\
\hline 2 & $2 \operatorname{Jan} 2017$ & 719.50 & 282 & $2,158,500.00$ & 0.39 \\
\hline 3 & $3 \operatorname{Jan} 2017$ & 713.70 & 283 & $2,141,100.00$ & 0.40 \\
\hline 4 & $4 \operatorname{Jan} 2017$ & 709.70 & 283 & $2,129,100.00$ & 0.40 \\
\hline 5 & $5 \operatorname{Jan} 2017$ & 737.00 & 292 & $2,211,000.00$ & 0.40 \\
\hline 6 & $6 \operatorname{Jan} 2017$ & 745.70 & 295 & $2,237,100.00$ & 0.40 \\
\hline 7 & $7 \operatorname{Jan} 2017$ & 741.50 & 295 & $2,224,500.00$ & 0.40 \\
\hline 8 & $8 \operatorname{Jan} 2017$ & 771.70 & 305 & $2,315,100.00$ & 0.40 \\
\hline 9 & $9 \operatorname{Jan} 2017$ & 761.40 & 302 & $2,284,200.00$ & 0.40 \\
\hline 10 & $10 \operatorname{Jan} 2017$ & 735.00 & 295 & $2,205,000.00$ & 0.40 \\
\hline 11 & $11 \operatorname{Jan} 2017$ & 783.30 & 310 & $2,349,900.00$ & 0.40 \\
\hline 12 & $12 \operatorname{Jan} 2017$ & 791.00 & 311 & $2,373,000.00$ & 0.39 \\
\hline 13 & $13 \operatorname{Jan} 2017$ & 791.70 & 311 & $2,375,100.00$ & 0.39 \\
\hline 14 & $14 \operatorname{Jan} 2017$ & 751.30 & 303 & $2,253,900.00$ & 0.40 \\
\hline 15 & $15 \operatorname{Jan} 2017$ & 798.10 & 312 & $2,394,300.00$ & 0.39 \\
\hline 16 & $16 \operatorname{Jan} 2017$ & 779.50 & 307 & $2,338,500.00$ & 0.39 \\
\hline 17 & $17 \operatorname{Jan} 2017$ & 763.50 & 299 & $2,290,500.00$ & 0.39 \\
\hline 18 & $18 \operatorname{Jan} 2017$ & 759.70 & 298 & $2,279,100.00$ & 0.39 \\
\hline 19 & $19 \mathrm{Jan} 2017$ & 754.70 & 296 & $2,264,100.00$ & 0.39 \\
\hline 20 & $20 \operatorname{Jan} 2017$ & 756.40 & 297 & $2,269,200.00$ & 0.39 \\
\hline 21 & $21 \operatorname{Jan} 2017$ & 749.00 & 294 & $2,247,000.00$ & 0.39 \\
\hline 22 & $22 \operatorname{Jan} 2017$ & 751.70 & 297 & $2,255,100.00$ & 0.40 \\
\hline 23 & $23 \mathrm{Jan} 2017$ & 751.50 & 296 & $2,254,500.00$ & 0.39 \\
\hline 24 & $24 \operatorname{Jan} 2017$ & 706.90 & 278 & $2,120,700.00$ & 0.39 \\
\hline 25 & $25 \mathrm{Jan} 2017$ & 714.30 & 281 & $2,142,900.00$ & 0.39 \\
\hline 26 & $26 \operatorname{Jan} 2017$ & 734.30 & 290 & $2,202,900.00$ & 0.39 \\
\hline 27 & $27 \operatorname{Jan} 2017$ & 715.00 & 282 & $2,145,000.00$ & 0.39 \\
\hline 28 & $28 \mathrm{Jan} 2017$ & 695.80 & 274 & $2,087,400.00$ & 0.39 \\
\hline 29 & $29 \mathrm{Jan} 2017$ & 708.90 & 280 & $2,126,700.00$ & 0.39 \\
\hline 30 & $30 \mathrm{Jan} 2017$ & 733.90 & 290 & $2,201,700.00$ & 0.40 \\
\hline 31 & $31 \operatorname{Jan} 2017$ & 751.50 & 295 & $2,254,500.00$ & 0.39 \\
\hline
\end{tabular}

Kebutuhan listrik untuk masyarakat Desa Temajuk, antara 450Watt sd 900Watt per sambungan rumah tangga $(220 \mathrm{~V}, 4 \mathrm{~A})$. Alokasi utama penggunaan listrik masyarakat pedesaan umumnya adalah untuk penerangan pada malam hari dan televisi, dengan pertimbangan pada siang hari sebagian besar masyarakat bekerja diluar rumah sesuai dengan pekerjaannya.

Tabel 6. Kebutuhan Daya Listrik Pedesaan

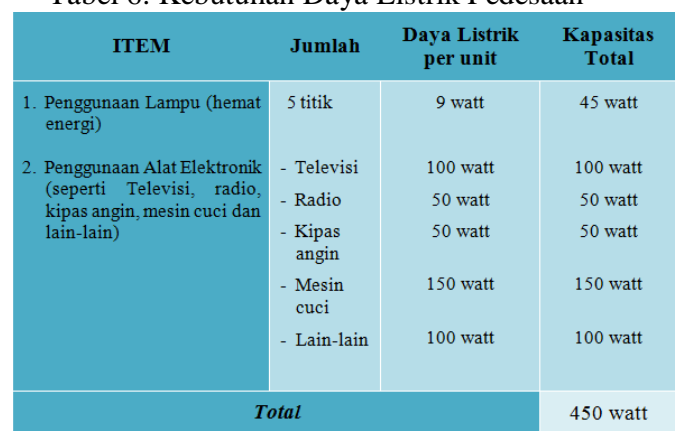

Berdasarkan data terakhir hingga Desember 2014, jumlah bangunan yang membutuhkan energi listrik di Desa Temajuk adalah 500 pelanggan yang terdiri dari 487 unit rumah tangga masyarakat dan 13 unit sarana 
umum termasuk gedung kantor. Sumber data dari Badan Pusat Statistik Sambas.

Tabel 7. Data Jaringan dan Daya Terpasang

\begin{tabular}{|c|c|c|c|c|c|}
\hline No. & Pembangkit & $\begin{array}{c}\text { Tegangan } \\
\text { Menengah } \\
\text { (kms) }\end{array}$ & $\begin{array}{c}\text { Tegangan } \\
\text { Rendah } \\
\text { (kms) }\end{array}$ & $\begin{array}{l}\text { Travo } \\
\text { (kVa) }\end{array}$ & $\begin{array}{c}\text { Daya } \\
\text { Terpasang } \\
\text { (kW) }\end{array}$ \\
\hline 1. & PLTMH & - & 2,3 & - & 18 \\
\hline 2. & PLTS Terpusat & - & 1,4 & - & 70 \\
\hline 3. & PLTD & 5 & 2,4 & $3(100)$ & 100 \\
\hline
\end{tabular}

\subsection{Studi Microgrid System di Desa Temajuk}

Model yang digunakan untuk studi lebih lanjut ke dalam perilaku microgrid system dan pengembangan model yang lebih akurat.

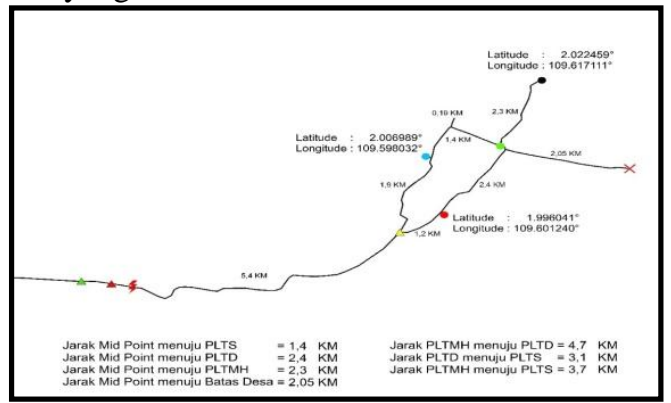

Gambar 10. Peta Jaringan dan Pembangkit Microgrid System

Jaringan distribusi microgrid system menggunakan jaringan tegangan rendah dengan konduktor jenis $T C$ (twisted cable) tanpa menggunakan jaringan tegangan menengah dan trafo.

1. Jaringan distribusi PLTS Terpusat.

Penggunaan jaringan distribusi dalam microgrid system Desa Temajuk menggunakan jaringan tegangan rendah dengan konduktor jenis TC (twisted cable) ukuran $2 \times(3 \times 50+1 \times 50) \mathrm{mm}^{2}$ dengan panjang lintasan $1,4 \mathrm{kms}$.

$P 3 \emptyset=70 \mathrm{kWp}$

$I 1=\frac{P 3 \emptyset}{\sqrt{3 \times V 1}-1 \times \operatorname{Cos} \varphi}$

$I 1=\frac{70.000 w P}{\sqrt{3} \times 380 \times 0.85}$

$I 1=\frac{70.000 \mathrm{wP}}{559.44}=125 \mathrm{Amp}$

Asumsi beban Total PLTS Terpusat :

$P 1=50 k W p$

$I 1=\frac{50.000 \mathrm{wP}}{559.44}=89 \mathrm{Amp}$

Dengan kabel TC ukuran $2 \times(3 \times 70+1 \times$ 50) $\mathrm{mm}^{2}$ dan panjang lintasan $1,4 \mathrm{kms}$ dengan resistensi konduktornya $=0,401 \Omega / \mathrm{km}$.

maka, Resistensi Total :

Res Tot $=\frac{\text { Resistensi Konduktor }}{2} \times$ Panjang Lintasan

Resistensi Total $=\frac{0.401 \Omega / \mathrm{km}}{2} \times 1.4 \mathrm{kms}$

$=0,28 \Omega$

$\mathrm{V}$ drop Tegangan $=\mathrm{I} 1 \times$ Resistensi

$=89 \mathrm{Amp} \times 0.28 \Omega$

$=24.29$ Volt
Sehingga tegangan pada ujung saluran jaringan kabel TC tersebut apabila tegangan pada sumber pembangkit sebesar 230 Volt dengan panjang lintasan 1,4 kms adalah : Tegangan ujung saluran $=230$ Volt $-\mathrm{V}$ drop

$=230 \mathrm{Volt}-24.29 \mathrm{Volt}$

$=205.08 \mathrm{Volt}$

2. Jaringan distribusi PLTMH.

Penggunaan jaringan distribusi dalam microgridsystemDesa Temajuk menggunakan jaringan tegangan rendah dengan konduktor jenis TC (twisted cable $)$ ukuran $(3 \times 70+1 \times 50) \mathrm{mm}^{2}$ dengan panjang lintasan $2,3 \mathrm{kms}$.

$$
P 3 \emptyset=18 k W p
$$

Dengan menggunakan persamaan maka :

$$
\begin{aligned}
I 1 & =\frac{18.000 w P}{559.44} \\
& =32.18 \mathrm{Amp}
\end{aligned}
$$

Asumsi beban total PLTMH :

$P 1=10 \mathrm{~kW}$, maka dengan menggunakan persamaan

$$
\begin{aligned}
I 1 & =\frac{10.000 \mathrm{Watt}}{559.44} \\
& =17.88 \mathrm{Amp}
\end{aligned}
$$

Untuk konduktor jenis TC (twisted cable) dan ukuran penghantar $(3 \times 70+1 \times 50) \mathrm{mm}^{2}$ dan besar resistensi konduktor $0.401 \Omega$ dengan panjang lintasan $2,3 \mathrm{kms}$. maka Resistensi Total adalah :

Resistensi Total $=$

Resistensi Konduktor $\times$ Panjang Lintasan

$$
\begin{gathered}
=0.401 \Omega \times 2.3 \mathrm{kms} \\
=0.92 \Omega
\end{gathered}
$$

Jadi, tegangan ujung saluran jaringan kabel $T C$ ukuran $(3 \times 70+1 \times 50) \mathrm{mm}^{2}$ dengan panjang lintasan $2,3 \mathrm{kms}$, maka dengan menggunakan persamaan:

$$
\begin{aligned}
\mathrm{V} \text { drop } & =17.88 \mathrm{Amp} \times 0.92 \Omega \\
& =16.45 \mathrm{Volt}
\end{aligned}
$$

Sehingga tegangan pada ujung saluran jaringan kabel $T C$ tersebut apabila tegangan pada ${ }^{4}$ strmber pembangkit sebesar 230Volt dengan panjang lintasan 2,3kms adalah :

Tegangan Ujung Saluran $=230$ Volt $\times 16.45$ Volt $=213$ Volt

\section{Jaringan distribusi PLTD}

Penggunaan jaringan distribusi dalam microgrid system Desa Temajuk menggunakan jaringan tegangan rendah dengan konduktor jenis TC (twisted cable) ukuran $3 \times(3 \times 95+1 \times 70) \mathrm{mm}^{2}$ dengan panjang lintasan $2,4 \mathrm{kms}$.

$$
\begin{gathered}
P 3 \emptyset=100 \mathrm{kVa} \\
\operatorname{Cos} \varphi=0.85 \\
P 3 \emptyset=85 \mathrm{~kW}
\end{gathered}
$$

Asumsi Pl $=60 \mathrm{~kW}$

maka, dengan menggunakan persamaan:

$$
\begin{aligned}
& \mathrm{I} 1=\frac{60.000 \mathrm{~W}}{\left.559.44^{4} .3\right)} \\
& =107.25 \mathrm{Amp}
\end{aligned}
$$

Dengan kabel TC ukuran3 $\times(3 \times 95+1 \times$ 70) $\mathrm{mm}^{2}$ dan resistensi konduktornya $=0,324 \Omega / \mathrm{km}$ dengan panjang lintasan $2,4 \mathrm{kms}$. 
Maka resistensi total dengan menggunakan persamaan adalah :

$$
\begin{gathered}
\text { Resistensi Total }=\frac{0.324 \Omega / \mathrm{km}}{3} \times 2.4 \mathrm{kms} \\
=0.26 \Omega
\end{gathered}
$$

$\mathrm{V}$ drop tegangan jaringan ujung dengan menggunakan persamaa (4.3) adalah :

$$
\begin{aligned}
\mathrm{V} d r o p & =107.25 \mathrm{Amp} \times 0.26 \Omega \\
& =27.89 \mathrm{Volt}
\end{aligned}
$$

Sehingga tegangan pada ujung saluran jaringan kabel $T C$ tersebut apabila tegangan pada sumber pembangkit sebesar 230Volt dengan panjang lintasan 2,4kms adalah : Tegangan Ujung Saluran $=230$ Volt $-\mathrm{V}$ drop $=230 \mathrm{Volt}-27.89 \mathrm{Volt}$

$=202.11 \mathrm{Volt}$

Berdasarkan data beban harian PLTD Temajuk PLN Rayon Sekura, maka dapat dirancang sebagai berikut :

1. Pada siang hari.

- Pada siang hari modul surya $(P V)$ dipakai untuk mengisi batteray dengan kondisi posisi saklar S1 "ON".

- PLTMH dan PLTD kondisiposisi saklar S2 dan S3 "OFF".

2. Pada pukul 18:00 sampai dengan pukul 22:00

- Menjadi beban puncak (Peak-Load)

- Beban akan di supply oleh PLTD posisi saklar "ON".

- Lama waktu pengoperasian selama 4(empat) jam.

- PLTMH dan PLTS Terpusat posisi saklar "OFF",

3. Pada pukul 22:00 sampai dengan 06:00

- Beban akan menurun posisi saklar PLTD "OFF".

- Beban akan di supply oleh PLTMH bersama-sama dengan PLTS Terpusat posisi saklar "ON".

- Lama waktu pengoperasian selama 8(delapan) jam.

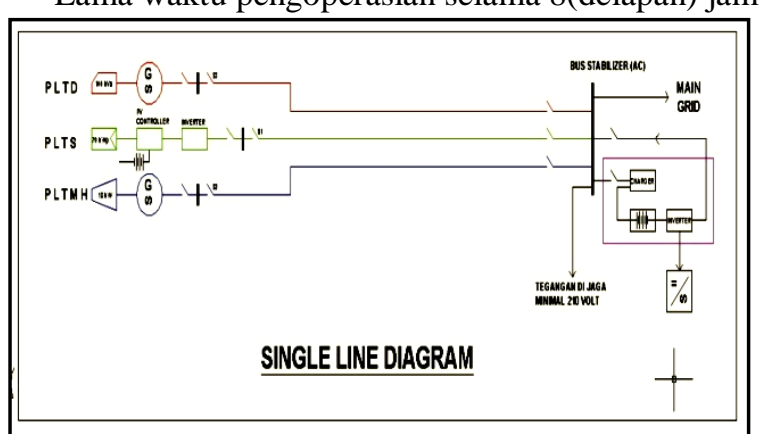

Gambar 11. Diagram Satu Garis Studi Microgrid System Desa Temajuk

Biaya operasional dari sisi bahan bakar minyak PLTD Temajuk saat ini (sebelum penggabungan) yang bekerja selama 12(dua belas) jam mulai dari pukul 1800 sampai dengan 0600 memikul beban pelanggan sangat membebani operator (PLN Rayon Sekura). Biaya ratarata operasional penggunaan bbm PLTD Rp. 2,235,338.71/hari dan total operasi selama satu bulan mulai dari tanggal 01 sampai dengan 31 Januari 20017 mencapai Rp. 69,295,500.00/bulan, data dari PT. PLN Area Singkawang Rayon Sekura.

Setelah dilakukan penggabungan pola beban maka, terjadi penghematan biaya operasional dari sisi penggunaan bbm PLTD rata-rata Rp. 961,790.32/hari dan total operasional satu bulan mulai tanggal 01 sampai dengan 31 Januari 2017 mencapai Rp. 29,815,500.00/bulan. Untuk membangkitkan $1 \mathrm{kWh}$ energi PLTD membutuhkan biaya Rp. 3000,00 bahan

\begin{tabular}{|c|c|c|c|c|c|c|c|c|}
\hline No. & 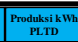 & $\begin{array}{l}\text { datskikw } \\
\text { pliss }\end{array}$ & 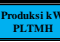 & 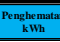 & 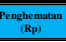 & 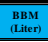 & 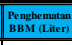 & 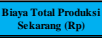 \\
\hline & $\begin{array}{l}161630 \\
20300\end{array}$ & $\begin{array}{l}480 \\
300\end{array}$ & 80 & 560.000 & 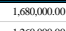 & $\begin{array}{l}63.73 \\
143\end{array}$ & 221.27 & 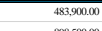 \\
\hline & 2020.50 & 300 & 120 & $\begin{array}{l}420.000 \\
420.00\end{array}$ & 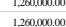 & $\begin{array}{l}171,39 \\
116464\end{array}$ & 10654 & 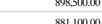 \\
\hline & 20270 & 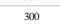 & 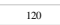 & 420000 & 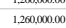 & 1115.52 & 16784 & \\
\hline & 317000 & 300 & 120 & 420.000 & 1.2010000 & 125.60 & 16640 & $951,1000,0$ \\
\hline & & 300 & 120 & 420.000 & 12001000 & 128.85 & 160.15 & 97.100000 \\
\hline & 312150 & 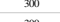 & 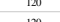 & 420000 & Danowis & 127.91 & 160.09 & 964500000 \\
\hline & 3 & 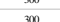 & 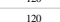 & $\infty$ & 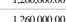 & 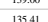 & 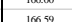 & W \\
\hline & 315. & 300 & 120 & 420000 & 12500000 & 120.43 & 1.8587 & $x_{s i s m}$ \\
\hline & & & & & & & 16622 & \\
\hline & 371.00 & 300 & 120 & 420.00 & 1000000 & 145.87 & 165.13 & 1.13:300, \\
\hline & 317.70 & 300 & 120 & 420.000 & 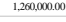 & 146.01 & 16999 & 1.1510000 \\
\hline 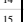 & 313.120 & 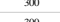 & & 420.000 & 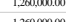 & 133601 & 1693939 & \\
\hline & 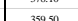 & & & w & & 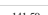 & 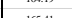 & \\
\hline & $33: 30$ & 300 & & 4200 & :100.000 & 1359 & 1648 & 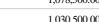 \\
\hline 18 & 39977 & 300 & 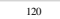 & 420.00 & 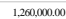 & 1325 & 16775 & 109101000 \\
\hline & 347.70 & 300 & 120 & 420.00 & 00.000 & 133.27 & 16473 & 1,0541000 \\
\hline & $36+40$ & 300 & 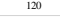 & 420.000 & 00,000 & 132.09 & 16491 & 109202010 \\
\hline & & (3) & & 4201060 & & 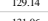 & 106:36.8 & $=0000-0$ \\
\hline & 31110 & 3000 & & 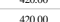 & nowe & 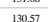 & 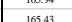 & 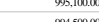 \\
\hline & 286.90 & & & $\infty$ & 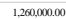 & & & 860727000 \\
\hline & 204.30 & 300 & 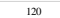 & 420.00 & 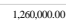 & 115.78 & 16522 & 2900000 \\
\hline & 31430 & 300 & 120 & 420.00 & & 124.13 & 15687 & 92125000.0 \\
\hline & 205500 & 300 & 120 & 420.00 & 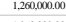 & 166.35 & 15.65 & $8 \sin \infty$ \\
\hline & & 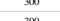 & & 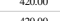 & & tratal & 10.39.99 & \\
\hline & 311200 & & & 4200 & & 12404 & 10596 & 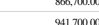 \\
\hline & 33150 & 300 & 120 & 420.00 & 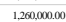 & 130.13 & 10687 & 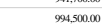 \\
\hline
\end{tabular}
bakar minyak jenis solar.

Tabel 8. Data Hasil Penghematan BBM PLTD Setelah Penggabungan

\section{Kesimpulan}

Dari hasil Penelitian maka dapat disimpulkan, bahwa :

1. Lamawaktu operasional PLTD menjadi 4(empat) jam dalam sehari setelah penggabungan pembangkit PLTMH dan PLTS Terpusat dalam Microgrid System.

2. Lama waktu operasional PLTMH dan PLTS Terpusat selama 8(delapan) jam dalam sehari selama penggabungan Microgrid System.

3. Terjadi penghematan biaya dari sisi penggunaan bbm PLTD sebesar 57\% dalam sebulan setelah terjadinya penggabungan pembangkit PLTMH, PLTS Terpusat dan PLTD dalam Microgrid System.

4. Daya terpasang PLTD yang diperlukan cukup $100 \mathrm{~kW}$ dalam Microgrid System saat ini.

\section{Referensi}

[1] J. D. Kueck, R. H. Stauton, S. D. Labinov, B. J. Kirby. January 29, 2003. Microgrid Energy Management System

[2] Robert H. Lasseter, Paolo Piagi University of WisconsinMadison Madison, Wisconsin Germany, 20-25 June 2004. Microgrid : A Conceptual Solution

[3] Giuliani Marshall, Supervisor : Dr. Colin Cotes. The University of Newcastle, Australia Oktober 2004 Modelling of a Micro-grid System

[4] Arwindra Rizqiawan, March 4, 2009. Microgrid : Wacana Solusi Daerah Mandiri Energi

[5] $\boldsymbol{B P P T}$, Program Insentif Riset Litbang Perekayasa. 2010 Desain Sistem Pendukung Operasi Jaringan Pembangkit Energi Terbarukan Skala Kecil Tersebar Dengan Teknologi Microgrid 
[6] Kazuhito Ishida (presenter), Yoshihide Shimogawa, Tadakazu Imayoshi, Koji Takano, Hidemi Hayashi, ToshikazuYamada, and Toshirou Noguchi Kyushu Electric Power Co., Inc.

[7] Takehiko Kojima and Toshiharu Mounai Fuji Electric System Co., Ltd.

[8] Hassan Feroze, August $7^{\text {th }}$, 2009. Multi-Agent System in Microgrid : Design and Implementation 